\title{
Ventilator-associated pneumonia is an important risk factor for mortality after major cardiac surgery
}

\author{
Eduardo Tamayo MD, PhD ${ }^{a}$, Francisco Javier Álvarez MD, $\mathrm{PhD}^{\mathrm{b}}$, \\ Beatriz Martínez-Rafael MD ${ }^{a}$, Juan Bustamante MD, PhD $^{c, *}$, \\ Jesus F. Bermejo-Martin MD, PhD ${ }^{d}$, Inma Fierro MD $^{b}$, Jose Maria Eiros MD, PhD $^{e}$, \\ Javier Castrodeza MD, PhD $^{f}$, Maria Heredia MD ${ }^{a}$, José I. Gómez-Herreras MD, PhD $^{g}$ \\ Valladolid Sepsis Study Group
}

\author{
a Department of Anaesthesiology and Intensive Care, Hospital Clinico Universitario de Valladolid, Valladolid, Spain 47005 \\ ${ }^{\mathrm{b}}$ Department Pharmacology and Therapeutics, Facultad de Medicina, Universidad de Valladolid, Valladolid, Spain 47005 \\ ${ }^{\mathrm{c}}$ Department of Cardiovascular Surgery, Hospital Universitario La Princesa, Madrid, Spain 28006 \\ dinfection \& Immunity Unit, Hospital Clinico Universitario de Valladolid-IECSCYL, Valladolid, Spain 47005 \\ e Department of Microbiology, Hospital Clinico Universitario de Valladolid, Valladolid, Spain 47005 \\ ${ }^{\mathrm{f}}$ Direction of Public Health, Investigation, Development and Innovation, SACYL, Valladolid, Spain 47007 \\ ${ }^{\mathrm{g}}$ Department of Anaesthesiology and Intensive Care, Hospital Universitario Rio Hortega, Valladolid, Spain 47012
}

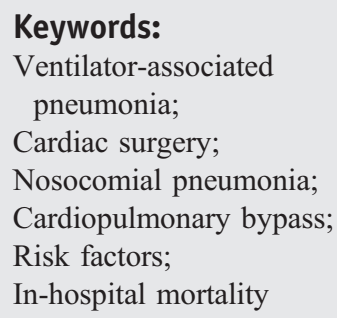

\begin{abstract}
Purpose: Ventilator-associated pneumonia (VAP) is the main infectious complication in cardiac surgery patients and is associated with an important increase in morbidity and mortality. The aim of our study was to analyze the impact of VAP on mortality excluding other comorbidities and to study its etiology and the risk factors for its development.

Materials and Methods: This prospective cohort study included 1610 postoperative cardiac surgery patients' status post cardiopulmonary bypass (CPB) between July 2004 and January 2008. The primary outcome measures were the development of VAP and in-hospital mortality.

Results: Ventilator-associated pneumonia was observed in 124 patients (7.7\%). Patients with VAP had a longer length of hospitalization $(40.7 \pm 35.1$ vs $16.1 \pm 30.1$ days, $P<.0001)$ and greater in-hospital mortality $(49.2 \%$ [61/124] vs $2.0 \%$ [30/1486], $P=.0001)$ in comparison with patients without VAP. After performing the Cox multivariant analysis adjustment, VAP was identified as the most important independent mortality risk factor (adjusted hazard ratio [HR], 8.53; 95\% confidence interval, 4.21-
\end{abstract}

Funding sources: This work was supported in part by a grant from the "Gerencia de Salud, Consejería de Sanidad, Junta de Castilla y Leon" (GRS 143/A/ 07) and the Ministry of Health (RD06/0001/0020). All the authors carefully read the manuscript and fully approved it. The manuscript is original, and it is not submitted anywhere other than your journal. The authors declare not having conflict of interest regarding this study.

is is Contribution of authors: ET and FJA conceived the idea, designed the protocol, and supervised the analysis of the results. JB and BMR contributed to obtain the funding, oversaw the study, and acted as guarantors for the report. BMR, JB, JFBM, JC, JME, FJA, ET, JC, and JIGH helped in the conception of the study and the design of the protocol, supervised the recruitment of patients, collected the clinical material, and were responsible for statistical analysis. ET, IF, $\mathrm{MH}, \mathrm{FJA}$, and JB developed and supervised all work and analyzed the results. ET wrote the report in collaboration with FJA, JIGH, JB, and the other authors.

* Corresponding author. Tel.: +34 636237393; fax: +34 915202201.

E-mail address: jbustamantemunguira@gmail.com (J. Bustamante). 
17.30; $P=.0001)$. Other independent risk factors of in-hospital mortality were chronic renal failure (HR, 2.56), diabetes mellitus (HR, 1.90), CPB time (HR, 1.51), respiratory failure (HR, 2.13), acute renal failure (HR, 2.39), and mediastinal bleeding of at least $1000 \mathrm{~mL}$ (HR, 1.81).

Conclusions: The development of VAP after CPB is the most important independent risk factor for inhospital mortality. Identification of effective strategies for the prevention of VAP is needed. (C) 2012 Elsevier Inc. All rights reserved.

\section{Introduction}

Ventilator-associated pneumonia (VAP) is the most frequent serious infection among patients undergoing heart surgery. The prevalence of VAP is estimated to be $7.8 \%$ to $21.6 \%[1-3]$ and is associated with prolonged hospitalization $[4,5]$, increased health care costs [6], and a $15 \%$ to $45 \%$ attributable mortality [7].

In patients admitted to the intensive care unit (ICU), the extra mortality due to VAP remains a controversial issue in the literature. Previous studies have reached conflicting conclusions regarding the impact of VAP on mortality [1,8-17]. Although the gross mortality rate is high, there are doubts as to whether the higher mortality rate is due to VAP itself or to the seriousness of the underlying illness.

Patients undergoing heart surgery are at a particularly high risk for the development of VAP due to the presence of multiple comorbidities, frequent postoperative use of invasive devices (eg, intraaortic balloon counterpulsation, pulmonary artery catheter), and the common use of cardiopulmonary bypass (CPB). At the same time, inhospital patients are also at risk for multiple postoperative events (eg, myocardial infarction [MI], congestive heart failure, acute renal failure, strokes) $[1-4,16,18,19]$. These comorbidities complicate the evaluation of the impact of VAP on mortality [17]. The repercussions of VAP on inhospital mortality have not been adequately studied in the area of cardiac surgery.

Our working hypothesis was that VAP is the most important independent risk factor of in-hospital mortality in cardiac surgery patients. Our main objective was to assess whether the development of VAP during the postoperative period after cardiac surgery for patients undergoing CPB is associated with an excess of in-hospital mortality not attributable to the underlying severity of the illness or to the intraoperative and postoperative events. The secondary aim was to establish risk factors of in-hospital mortality.

\section{Materials and methods}

\subsection{Hospital setting and patients}

This prospective observational study was carried out in the "Hospital Clínico Universitario," a tertiary-level medical center with 800 beds in Valladolid, Spain. The
Department of Cardiac Surgery annually performs approximately 550 open cardiac operations with extracorporeal circulation in adult patients. Two operating rooms were routinely used. There was an ICU with 10 beds dedicated exclusively to the postoperative care of patients who had undergone cardiac surgery. During a 3.5-year period (July 2004-January 2008), all patients undergoing cardiac surgery with extracorporeal circulation were potentially eligible for this investigation; and follow-up continued until January 2009. No patient was excluded. Patients were excluded if they were younger than 18 years and if they had undergone heart transplantation. The hospital's research commission approved the study. All patients, preoperatively, provided informed written consent both for their heart surgery and for their participation in the study.

\subsection{Study design, end point, and data collection}

A prospective cohort study design was used to segregate study patients undergoing cardiac surgery with CPB according to the presence or absence of VAP. The 2 populations were compared for in-hospital end point of mortality.

One of the investigators made daily rounds in the ICU to identify eligible patients and to determine the onset of VAP based on the diagnostic criteria described below. Because this was strictly an observational study, the investigators did not interact with the ICU treating physicians regarding the diagnosis or management of VAP. Patients were evaluated for nosocomial pneumonia during mechanical ventilation and for 48 hours after extubation.

Demographic and clinical characteristics and the data concerning intraoperative and postoperative course (Table 1) were prospectively recorded for all patients.

\subsection{Techniques and treatment received}

The surgical and anesthetic techniques and the treatment the patient received in the ICU did not differ from ordinary procedures. After admission to the ICU and verification of hemodynamic stability, the patients were always placed at a position of $45^{\circ}$. Gastric protection was routinely carried out with ranitidine ( $50 \mathrm{mg}$ intravenously per 12 hours) during the first 24 hours of admission in the ICU; if it continued to be required, ranitidine was replaced by sucralfate ( $1 \mathrm{~g}$ orally or through nasogastric tube every 8 hours). All patients were extubated in the ICU when hemodynamically stable, with a 
Table 1 Characteristics of preoperative, intraoperative, and postoperative data for patients with and without VAP

\begin{tabular}{|c|c|c|c|}
\hline Characteristics & $\begin{array}{l}\text { Patients } \\
\text { with VAP } \\
(\mathrm{n}=124)\end{array}$ & $\begin{array}{l}\text { Patients } \\
\text { without VAP } \\
(\mathrm{n}=1486)\end{array}$ & $P$ \\
\hline \multicolumn{4}{|l|}{ Preoperative values } \\
\hline Age (y) & $68.5 \pm 10.03$ & $67.8 \pm 10.5$ & .45 \\
\hline Sex, male/female & $\begin{array}{l}46(37.1) / \\
78(62.9)\end{array}$ & $\begin{array}{l}584(39.3) / \\
902(60.7)\end{array}$ & .62 \\
\hline \multicolumn{4}{|l|}{ Underlying conditions } \\
\hline Chronic renal failure & $19(15.3)$ & $61(4.1)$ & .0001 \\
\hline $\begin{array}{l}\text { Peripheral vascular } \\
\text { disease }\end{array}$ & $6(6.6)$ & $1(0.1)$ & .0001 \\
\hline Congestive heart failure & $19(15.3)$ & $4(0.3)$ & .0001 \\
\hline Hypertension & $70(56.5)$ & $609(41.0)$ & .001 \\
\hline Diabetes mellitus & $36(29.0)$ & $440(29.6)$ & .89 \\
\hline Malignant neoplasm & $6(4.8)$ & $0(0.0)$ & .0001 \\
\hline $\begin{array}{l}\text { Chronic obstructive } \\
\text { pulmonary disease }\end{array}$ & $32(25.8)$ & $336(22.6)$ & .41 \\
\hline Immunosuppression & $12(9.7)$ & $31(2.1)$ & .0001 \\
\hline Previous cardiac surgery & $8(6.5)$ & $43(2.9)$ & .03 \\
\hline Obesity & $17(13.7)$ & $458(30.8)$ & .0001 \\
\hline \multicolumn{4}{|l|}{ Intraoperative values } \\
\hline $\begin{array}{l}\text { Surgical procedure, } \\
\text { valve }\end{array}$ & $72(58.1)$ & $945(63.6)$ & .22 \\
\hline $\begin{array}{l}\text { Surgical procedure, } \\
\text { CABG }\end{array}$ & $34(27.4)$ & $631(42.5)$ & .001 \\
\hline $\begin{array}{l}\text { Surgical procedure, } \\
\text { valvular }+\mathrm{CABG}\end{array}$ & $15(12.1)$ & $15(1.0)$ & .0001 \\
\hline $\begin{array}{l}\text { Aortic cross-clamp, } \\
\text { (min) }\end{array}$ & $83.1 \pm 36.4$ & $67.4 \pm 28.0$ & .0001 \\
\hline Total CPB time (min) & $115.9 \pm 48.2$ & $94.1 \pm 37.2$ & .0001 \\
\hline \multicolumn{4}{|l|}{ Postoperative values } \\
\hline $\begin{array}{l}\text { Duration of mechanical } \\
\text { ventilation (d) }\end{array}$ & $25.2 \pm 26.2$ & $1.8 \pm 7.2$ & .0001 \\
\hline Cardiac complications & $57(46.0)$ & $39(2.6)$ & .0001 \\
\hline Respiratory failure & 89 (71.8) & $79(5.3)$ & .0001 \\
\hline Acute renal failure & $79(63.7)$ & $25(1.7)$ & .0001 \\
\hline Stroke & $10(8.1)$ & $9(0.6)$ & .0001 \\
\hline Reintervention & $8(6.5)$ & $43(2.9)$ & .03 \\
\hline $\begin{array}{l}\text { Mediastinal bleeding } \\
\geq 1000 \mathrm{~mL}\end{array}$ & $15(12.1)$ & $11(0.7)$ & .0001 \\
\hline $\begin{array}{l}\text { Gastrointestinal } \\
\text { complication }\end{array}$ & $16(12.9)$ & $3(0.2)$ & .0001 \\
\hline
\end{tabular}

Values are expressed as number (percentage) or means \pm SD. Probability value of $P \leq .05$ was considered to be significant.

Ramsay score of 2 to 3, Tobin index (respiratory rate [spontaneous]/tidal volume [liters]) less than 105 [20], partial pressure of arterial oxygen $\left(\mathrm{PaO}_{2}\right)$ greater than $60 \mathrm{~mm} \mathrm{Hg}$, fraction of inspired oxygen $\left(\mathrm{FIO}_{2}\right)$ less than 0.4 , continuous positive airway pressure less than $5 \mathrm{mbar}, \mathrm{PaCO}_{2} 50 \mathrm{~mm} \mathrm{Hg}$ and arterial $\mathrm{pH}$ greater than 7.35. Ratio $\mathrm{PaO}_{2} / \mathrm{FIO}_{2}$ greater than 200 , and there was no significant bleeding.

Mouthwashes with chlorhexidine were carried out twice a day. Antibiotic therapy for VAP was based on our prior experience in identifying the most common bacterial patho- gens associated with VAP in our medical ICU as well as following international guidelines [21]. Antibiotic administration included initial empirical treatment of methicillin-resistant Staphylococcus aureus with linezolid or teicoplanin and treatment of Pseudomonas aeruginosa with at least 1 of the following antibiotics: imipenem, cefepime, or piperacillintazobactam, in association with amikacin or ciprofloxacin.

\subsection{Definitions}

\subsubsection{Ventilator-associated pneumonia}

Ventilator-associated pneumonia was diagnosed upon the presence of new and/or progressive pulmonary infiltrates on a chest radiograph plus 2 or more of the following criteria: fever $\left(\geq 38.5^{\circ} \mathrm{C}\right)$ or hypothermia $\left(<36^{\circ} \mathrm{C}\right)$, leukocytosis $(\geq 12 \times$ $10^{9} / \mathrm{L}$ ), purulent tracheobronchial secretions, or a reduction in $\mathrm{PaO}_{2} / \mathrm{FIO}_{2}$ of at least $15 \%$ in the previous 48 hours, according to the definition of the Centers for Disease Control and Prevention [22]. Patients with a Pugin score greater than 6 were also included as having pneumonia [23]. The isolation of 1 or more pathogenic microorganisms in significant bacterial counts was required to confirm the diagnosis of VAP. We considered as nonpathogenic the isolation (at any concentration) of the following microorganisms unless proven otherwise: Viridans group streptococci, coagulasenegative Staphylococcus, Neisseria species, Corynebacterium species, and Candida species.

Inclusion in the study required collection of both respiratory and blood samples for microbiological examination. Sampling of the lower respiratory tract in cases of suspected VAP was performed by endotracheal aspiration (ETA) and/or telescopic brush sampling of respiratory secretions. For ETA, we obtained undiluted tracheal secretions. When aspiration was unproductive, we irrigated with $5 \mathrm{~mL}$ of Ringer lactate solution. Samples were considered to be positive for VAP when a bacterial count of at least $10^{4}$ colony-forming unit per milliliter for each microorganism was obtained by ETA and at least $10^{3}$ colony-forming units per milliliter was obtained by telescopic brushing. Episodes with more than 1 pathogenic microorganism isolated in respiratory samples were considered polymicrobial episodes.

\subsection{Appropriate antibiotic therapy}

Appropriate empirical antibiotic treatment was defined when at least 1 of the drugs administered was effective against the pathogens obtained on the antibiogram and administered immediately after the microbiological diagnostic test was carried out. The only exception was the case of $P$ aeruginosa, in which 2 effective drugs were required.

\subsection{Mortality}

In-hospital mortality was defined as patient deaths occurring from the moment the patient was admitted to the 
hospital. Intensive care unit mortality was defined as any death occurring while a patient was located in an ICU.

\subsection{Other postoperative events}

\subsubsection{Myocardial infarction}

Perioperative $M I$ was defined as a new $\mathrm{Q}$ wave on electrocardiogram by the Minnesota code criteria or myocardium-specific creatine kinase levels of at least $100 \mathrm{ng} / \mathrm{mL}$ after surgery [24].

\subsubsection{Stroke}

Stroke was defined as a focal brain injury that persisted for more than 24 hours combined with an increase in disability of at least 1 grade on the Rankin scale [25].

\subsubsection{Respiratory failure}

This was defined as prolonged ventilator therapy greater than 72 hours, reintubation, or tracheostomy [26].

\subsubsection{Gastrointestinal complication}

This was defined as the presence of any episode of digestive bleeding, cholecystitis, perforation, or necrosis of the stomach or intestine [26].

\subsubsection{Mediastinitis}

We used the definition described by the Centers for Disease Control and Prevention [22].

\subsubsection{Acute renal failure}

This was defined as a creatinine level higher than $2 \mathrm{mg} / \mathrm{dL}$ $(176.8 \mu \mathrm{mol} / \mathrm{L})$ or a $50 \%$ increase in creatinine level compared with baseline [27].

\subsection{Study variables}

\subsubsection{Outcome variables}

The primary outcome variable was in-hospital mortality.

\subsubsection{Independent variables}

Preoperative, intraoperative, and postoperative potential risk factors (see below) were defined as independent variables.

\subsection{Statistical analysis}

All values are expressed as the mean $\pm \mathrm{SD}$ (continuous variables) or as a percentage of the group they were derived from (categorical variables). Data were stored and analyzed by use of the software SPSS, version 15.0 (SPSS, Chicago, IL).

Univariate analysis was used to compare the variables for the outcome groups of interest (patients with VAP vs those without VAP and nonsurviving patients [in-hospital mortality] vs survivors). Comparisons were unpaired, and all tests of significance were 2 tailed. Numerical variables were compared using the Student $t$ test. The $\chi^{2}$ statistic or Fisher exact test was used to compare categorical variables.

The propensity for in-hospital mortality developing post coronary artery bypass graft (CABG) was determined using logistic regression analysis. The potential risk factors for in-hospital mortality (Table 3), (1) preoperative, (2) intraoperative, and (3) postoperative, were entered into the model. Because of the large number (25 variables) of potential risk factors, we avoided multicollinearity among the explanatory variables by performing collinearity diagnostic analyses. We performed the stepwise selection of variables from the models with the following criteria: tolerance greater than 0.4 [28] or variance inflation less than 2.5 [28], condition number less than 10 , and variance of 2 or more variables no greater than 0.5 [29,30]. Using the same criteria and variables as before, we carried out a new logistic regression analysis in which only patients with VAP were included.

Patient survival was described using the product-limit methodology of Kaplan-Meier. We used Cox proportional hazards analysis to calculate adjusted hazard ratios (HRs) and to risk adjust the Kaplan-Meier survival curve for differences in patient and disease characteristics [31]. Significance was assessed at the $P \leq .05$ level.

\section{Results}

\subsection{Patient and disease characteristics}

During the period of the study, a total of 1610 patients were included. Mean patient age was $67.8 \pm 10.3$ years. There were $60.9 \%(980 / 1610)$ men and $39.1 \%(630 / 1610)$ women. Ventilator-associated pneumonia after cardiac surgery developed in $124(7.7 \%)$ of patients, and the mean interval from surgery to presentation of VAP was $5.7 \pm 5.8$ days. In 80 (64\%) patients, the antibiotic therapy was appropriate.

Patients with VAP (Table 1) had more comorbid conditions, longer aortic cross-clamp time $(P<.0001)$, longer total CPB time $(P<.0001)$, longer duration of mechanical ventilation $(P<.0001)$, and more postoperative complications including cardiac complications, respiratory failure, acute renal failure, etc $(P<.0001)$. Patients with VAP had a longer length of ICU after surgery $(29.6 \pm 29.4 \mathrm{vs}$ $4.2 \pm 8.1$ days, $P<.001)$ and length of hospital stay (40.7 \pm 35.1 vs $16.1 \pm 30.1$ days, $P<.0001)$ in comparison with patients without VAP.

The most commonly isolated pathogens (Table 2) associated with a nosocomial infection were gram-negative bacilli ( $\mathrm{n}=92,74.2 \%)$, in particular, Acinetobacter $\mathrm{spp}(\mathrm{n}=$ $35,28.2 \%)$ and $P$ aeruginosa $(\mathrm{n}=26,20.9 \%)$, followed by gram-positive bacteria $(\mathrm{n}=57,45.9 \%)$, most commonly $S$ aureus $(\mathrm{n}=55$, or $44.3 \%)$, and yeast $(\mathrm{n}=15,12.1 \%)$. Ventilator-associated pneumonia was polymicrobial in 17 
Table 2 Pathogens isolated in patients with VAP

\begin{tabular}{lc}
\hline Microorganisms & $\begin{array}{c}\text { Patients with VAP } \\
(\mathrm{n}=124) \mathrm{n}(\%)\end{array}$ \\
\hline Gram negative & $92(74.2)$ \\
All & $35(28.2)$ \\
Acinetobacter spp & $3(2.4)$ \\
Escherichia coli & $15(12.1)$ \\
Haemophilus influenzae & $9(7.3)$ \\
Klebsiella spp & $1(0.8)$ \\
Proteus spp & $26(20.9)$ \\
P aeruginosa & $2(1.6)$ \\
Serratia spp & $1(0.8)$ \\
Stenotrophomonas maltophilia & \\
Gram positive & $57(45.9)$ \\
All & \\
S aureus & $55(44.3)$ \\
All & $25(20.1)$ \\
MSSA & $12(9.6)$ \\
MRSA & $2(1.6)$ \\
Streptococcus pneumoniae & $17(13.7)$ \\
Polymicrobial & MRSA indicates \\
\hline Values are expressed as number (percentage). MRA & \\
methicillin-resistant $S$ aureus; MSSA, methicillin-susceptible S aureus. &
\end{tabular}

patients (13.7\%). Bacteremia was present in 56 patients (44.8\%) with VAP.

\subsection{Hospital mortality and VAP}

The overall rate of in-hospital mortality was 5.6\% (91/1610), and ICU mortality was $4.5 \%$ (72/1610). Patients with VAP had higher in-hospital mortality (49.2\% [61/124] vs $2.0 \%$ [30/1486], $P=.0001)$ and ICU mortality $(41.9 \%[52 / 124]$ vs $1.3 \%$ [20/ $1486], P=.0001)$ in comparison with patients without VAP. The attributable in-hospital mortality in appropriately treated VAP was slightly lower than that in inappropriately treated VAP, but it was not statistically significant.

Univariate analysis showed that 19 of the 26 variables were associated with an increased risk of in-hospital mortality (Table 3). After the collinearity assessment, the aortic crossclamp time variable was dropped because of multicollinearity with the CPB time (Table 3). Eighteen variables were included in a multivariate analysis after withdrawal of those variables showing multicollinearity (Table 3 ).

The crude HR of mortality for patients with VAP was 13.28 (95\% confidence interval [CI], 6.14-28.72; $P<.0001)$. The unadjusted Kaplan-Meier survival curves are shown in Fig. 1. The adjusted freedom from death for VAP at 30, 60, and 90 days was $91.1 \%, 85.2 \%$, and $84.0 \%$, respectively, compared with $99.0 \%, 98.6 \%$, and $98.4 \%$ for patients without VAP $(P<.0001)$. After performing the Cox multivariant analysis adjustment for preoperative, intraoperative, and postoperative complications (Table 4), VAP was identified as the independent in-hospital mortality risk factor with the highest HR in patients undergoing cardiac surgery (HR, 8.53; 95\% CI, 4.21-17.305; $P=.0001)$. Also
Table 3 Univariate analysis of potential preoperative, intraoperative, and postoperative risk factors for in-hospital mortality after cardiac surgery

\begin{tabular}{|c|c|c|c|}
\hline Characteristics & $\begin{array}{l}\text { Nonsurvivors } \\
(\mathrm{n}=91)\end{array}$ & $\begin{array}{l}\text { Survivors } \\
(\mathrm{n}=1519)\end{array}$ & $P$ \\
\hline \multicolumn{4}{|l|}{ Preoperative values } \\
\hline Age $(y)$ & $69.9 \pm 9.7$ & $67.7 \pm 10.6$ & .06 \\
\hline Sex, male/female & $\begin{array}{l}51(56.0) / \\
40(44.0)\end{array}$ & $\begin{array}{l}929(61.2) / \\
590(38.8)\end{array}$ & .33 \\
\hline \multicolumn{4}{|l|}{ Underlying conditions } \\
\hline Chronic renal failure & 19 (20.9) & $61(4.0)$ & .0001 \\
\hline $\begin{array}{l}\text { Peripheral vascular } \\
\text { disease }\end{array}$ & $6(6.6)$ & $1(0.1)$ & .0001 \\
\hline $\begin{array}{l}\text { Congestive heart } \\
\text { failure }\end{array}$ & $9(9.9)$ & $14(0.9)$ & .0001 \\
\hline Hypertension & $50(54.9)$ & $629(41.4)$ & .01 \\
\hline Diabetes mellitus & $35(38.5)$ & $441(29.0)$ & .05 \\
\hline Malignant neoplasm & $3(3.3)$ & $3(0.2)$ & .0001 \\
\hline $\begin{array}{l}\text { Chronic obstructive } \\
\text { pulmonary disease }\end{array}$ & $28(30.8)$ & $340(22.4)$ & .06 \\
\hline Immunosuppression & $7(7.7)$ & $36(2.4)$ & .002 \\
\hline $\begin{array}{l}\text { Previous cardiac } \\
\text { surgery }\end{array}$ & $4(4.4)$ & $47(3.1)$ & .49 \\
\hline Obesity & $19(20.9)$ & $456(30.0)$ & .06 \\
\hline \multicolumn{4}{|l|}{ Intraoperative values } \\
\hline $\begin{array}{l}\text { Surgical procedure, } \\
\text { valve }\end{array}$ & $58(63.7)$ & $959(63.1)$ & .908 \\
\hline $\begin{array}{l}\text { Surgical procedure, } \\
\text { CABG }\end{array}$ & $24(26.4)$ & $641(42.2)$ & .003 \\
\hline $\begin{array}{l}\text { Surgical procedure, } \\
\text { valvular }+ \text { CABG }\end{array}$ & $11(12.1)$ & $19(1.3)$ & .0001 \\
\hline $\begin{array}{l}\text { Aortic cross-clamp } \\
\text { time }(\min )^{a}\end{array}$ & $86.7 \pm 34.1$ & $67.9 \pm 28.3$ & .0001 \\
\hline Total CPB time (min) & $122.4 \pm 46.3$ & $94.1 \pm 37.5$ & .0001 \\
\hline \multicolumn{4}{|l|}{ Postoperative values } \\
\hline $\begin{array}{l}\text { Duration of mechanical } \\
\text { ventilation }(h)\end{array}$ & $599.5 \pm 611.1$ & $58.8 \pm 217.4$ & .0001 \\
\hline VAP & $61(67.0)$ & $63(4.1)$ & .0001 \\
\hline $\begin{array}{l}\text { VAP appropriate } \\
\text { antibiotic therapy }\end{array}$ & $35(38.4)$ & $45(2.9)$ & .102 \\
\hline Cardiac complications & $35(38.5)$ & $61(4.0)$ & .0001 \\
\hline Respiratory failure & $57(62.6)$ & $111(7.3)$ & .0001 \\
\hline Acute renal failure & $49(53.8)$ & $55(3.6)$ & .0001 \\
\hline Stroke & $5(5.5)$ & $14(0.9)$ & .0001 \\
\hline $\begin{array}{l}\text { Mediastinal bleeding } \\
\geq 1000 \mathrm{~mL}\end{array}$ & $7(7.7)$ & $19(1.3)$ & .0001 \\
\hline $\begin{array}{l}\text { Gastrointestinal } \\
\text { complication }\end{array}$ & $12(13.2)$ & $7(5)$ & .0001 \\
\hline
\end{tabular}

identified as independent risk factors of in-hospital mortality were chronic renal failure (HR, 2.56), diabetes mellitus (HR, 1.90), CPB time (HR, 1.51), respiratory failure (HR, 2.13), acute renal failure (HR, 2.39), and mediastinal bleeding of at least $1000 \mathrm{~mL}$ (HR, 1.81). The adjusted Kaplan-Meier survival curves are shown in Fig. 2. The adjusted freedom 


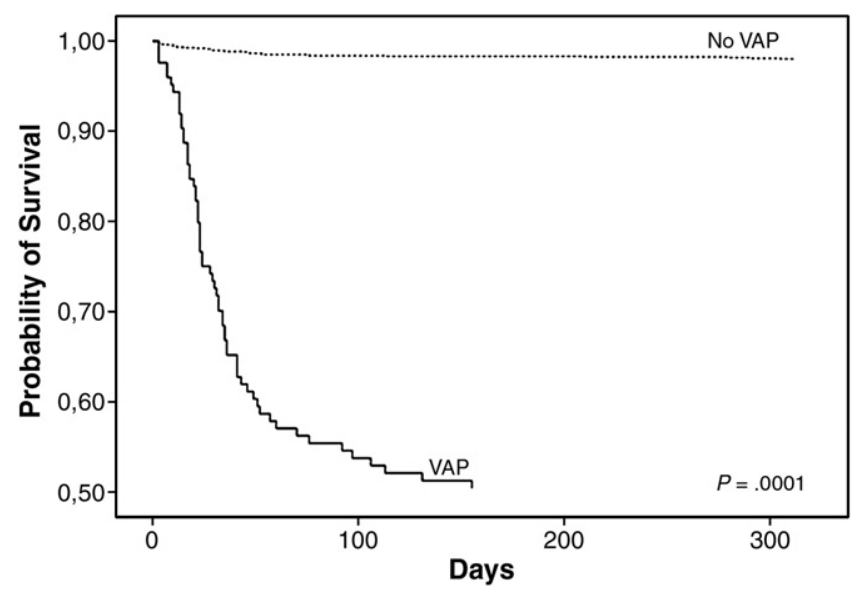

Fig. 1 Kaplan-Meier curves showing survival of patients with ventilator-associated pneumonia (VAP) after cardiopulmonary bypass (CPB) compared with patients without VAP. Comparison between groups was performed with the log-rank test.

from death for VAP at 30, 60, and 90 days was $72.6 \%$, $57.1 \%$, and $53.8 \%$, respectively, as compared with $98.9 \%$, $98.5 \%$, and $98.3 \%$ for patients without VAP $(P<.0001)$.

In the 124 patients with VAP, the Cox multivariant analysis adjustment for preoperative, intraoperative, and postoperative complications identified as independent risk factors of in-hospital mortality chronic renal failure (HR, 2.70), diabetes mellitus (HR, 2.02), and acute renal failure (HR, 2.67) (Table 5). Appropriately treated VAP was not found to be an independent risk factor for in-hospital mortality.

\section{Discussion}

This prospective cohort study was designed to examine any potential effect of VAP on the in-hospital mortality of patients undergoing cardiac surgery with $\mathrm{CPB}$ and to differentiate this from the contributing factors concerning preoperative, intraoperative, and postoperative complications. In this context, the most relevant findings were that (1)

Table 4 Risk factors for in-hospital mortality after cardiac surgery determined by Cox regression analysis

\begin{tabular}{llll}
\hline Characteristics & $\begin{array}{l}\text { Adjusted } \\
\text { HR }\end{array}$ & $95 \%$ CI & $P$ \\
\hline Chronic renal failure & 2.56 & $1.51-4.33$ & .0001 \\
Diabetes mellitus & 1.90 & $1.22-2.95$ & .004 \\
CPB time & 1.51 & $1.16-1.97$ & .002 \\
VAP & 8.53 & $4.21-17.305$ & .0001 \\
Respiratory failure & 2.13 & $1.17-3.86$ & .012 \\
Acute renal failure & 2.39 & $1.34-4.27$ & .003 \\
Mediastinal bleeding & 1.81 & $1.107-2.97$ & .018 \\
$\quad \geq 1000 \mathrm{~mL}$ & & & \\
\hline
\end{tabular}

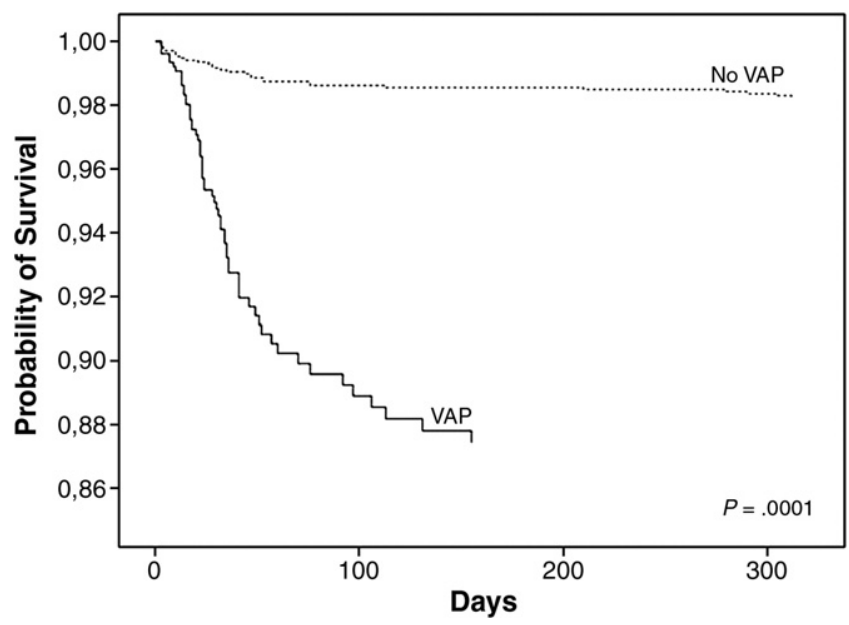

Fig. 2 Adjusted Kaplan-Meier curves (according to the COX method) showing survival of patients with ventilator-associated pneumonia (VAP) after cardiopulmonary bypass compared with patients without VAP, adjusted for preoperative, intraoperative, and postoperative risk factor.

the development of VAP during postoperative cardiac surgery is an important factor in determining in-hospital mortality, increasing the risk of death by 8.53 times, and (2) other risk factors of in-hospital mortality were chronic renal failure (HR, 2.56), diabetes mellitus (HR, 1.90), CPB time (HR, 1.51), respiratory failure (HR, 2.13), acute renal failure (HR, 2.39), and mediastinal bleeding of at least $1000 \mathrm{~mL}$ (HR, 1.81).

The stratification of risk in cardiac surgery has been centered on preoperative and intraoperative patient risk factors (eg, the Tuman, EuroSCORE, or Parsonnet scales of risk) [32-34]. The EuroSCORE [33], for example, summarizes prognostic factors such as age and sex, comorbidities (eg, chronic obstructive lung disease and neurologic impairment), cardiac factors (eg, ejection fraction, recent MI, and pulmonary artery hypertension), and the type of surgery [33]. This scoring tool was shown to predict shortterm [35] and long-term [36] mortality.

However, the results of surgery are not only determined by the patient's preoperative conditions but also depend on perioperative events such as perioperative myocardial ischemia, atrial fibrillation, transfusion, stroke, acute renal failure, time to extubation, etc, which are associated with

Table 5 Risk factors for in-hospital mortality in patients with VAP after cardiac surgery determined by Cox regression analysis

\begin{tabular}{llll}
\hline Characteristics & Adjusted HR & $95 \%$ CI & $P$ \\
\hline Chronic renal failure & 2.70 & $1.50-4.84$ & .001 \\
Diabetes mellitus & 2.02 & $1.18-3.45$ & .009 \\
Acute renal failure & 2.67 & $1.40-5.08$ & .003 \\
\hline
\end{tabular}


increased morbidity and mortality after cardiac surgery [24-27]. Thus, although most clinical studies analyze the results of cardiac surgery, they only focus on these complications, rarely analyzing the repercussions of the presence of VAP on in-hospital mortality.

Mortality in patients with VAP is a controversial subject concerning patients admitted to the ICU because the target population is severely ill and the level of associated mortality is high. Several studies have attempted to clarify the issue $[3,15,16]$. Bueno-Cavanillas et al $[15]$ found that critically ill patients with a nosocomial infection, mainly bacteremia and pneumonia, have a higher rate of mortality. Other studies, using univariate analysis, have suggested that VAP is associated with an increased risk of fatality; but this association was not evident in multivariate analyses $[10,11]$. The use of stepwise logistic regression to control for effects of confounding variables has shown that VAP increases the risk of death $[7,12,13]$, whereas others do not confirm these conclusions [14]. A recent meta-analysis showed no evidence of attributable mortality due to VAP in patients with trauma or acute respiratory distress syndrome. In other nonspecified patient groups, it was unclear due to heterogeneity whether mortality was attributable to VAP; and therefore, the study results could not be quantified [17]. Most of these studies have included patients with diverse pathologies (medical, surgical, trauma patients, etc), and this makes drawing conclusions difficult. In addition, the problem is further complicated by the different criteria and methods used to diagnose VAP, which in turn makes the comparison of results even more problematic [37].

Very few studies have been performed on postoperative cardiac surgery patients. Kollef et al [38], in a study that included 605 consecutive patients undergoing cardiac surgery, observed VAP in $9.7 \%$ of the patients. Thirty (5.0\%) patients died during hospitalization after cardiac surgery, and the mortality rate of patients with VAP was $23.7 \%$. Bouza et al [3] analyzed 356 patients and found a frequency of VAP of $7.8 \%$ with an overall mortality of $7.3 \%$. Death was significantly more frequent in patients with VAP $(57.1 \%)$ than in any other group. In a study of 1844 patients, Hortal et al [39] found that the cumulative incidence of VAP during the study period was $5.7 \%$. Overall in-hospital mortality in the study population was $6.9 \%$, with a mortality rate in patients with VAP of $45.7 \%$ vs $2.8 \%$ in patients without VAP $(P \leq .001)$. However, in a recent European multicenter study [40], a VAP incidence rate of $2.2 \%$, lower than that found in our and other studies $[3,38,39]$, was identified.

These studies included a smaller sample of patients with VAP than that enrolled here, and they did not take into account any conflicting factors and did not carry out multiple regression analyses to evaluate the real impact of VAP on patient mortality. The rates of VAP (7.7\%) and in-hospital mortality $(5.6 \%)$ in our study concur with previous findings. Our study, however, provides a larger patient sample size (124 patients with VAP). Furthermore, through Cox multiple regression, we determined that patients undergoing cardiac surgery who develop VAP have a risk of death 8.53 times higher than those without VAP. This study also shows the importance of other risk factors of mortality, including chronic renal failure, diabetes mellitus, CPB time, respiratory failure, acute renal failure, and mediastinal bleeding of at least $1000 \mathrm{~mL}$ [23-26].

Our study did not find lower mortality in patients with VAP who had received appropriate antibiotic therapy; however, inappropriateness in antibiotic treatment has been associated, in some studies, with worse outcomes in VAP $[41,42]$, although others have failed to prove this association $[16,21,43]$.

There are some issues that should be addressed. To begin with, this study included a single-center regional database. It is likely that the selection of patients, choice of procedures, as well as the management of the perioperative period may be important determinants of VAP; and these parameters vary widely among cardiac surgical units. Secondly, our study may be criticized for not evaluating the influence of variables that could influence the extent to which VAP increases mortality, such as causative pathogens, the presence of bacteremia, and the time of acquisition of VAP $[3,4,12,15,16]$. This study did not analyze the impact of such variables on the mortality rate of VAP simply because it was not the aim of this work. However, the study data referring to the average time before VAP commences (5.5 days), appropriate antibiotic therapy (64\%), presence of bacteremia (44.8\%), and the distribution of common isolated pathogens in cultures are in accordance with those found in other studies $[3,16,18,23,38,39]$.

This study provides data highlighting the clinical history of VAP in postoperative cardiac surgery patients. It suggests that the occurrence of VAP is the most important risk factor associated with in-hospital mortality. However, it cannot be discarded that other factors or comorbidities before the development of VAP might have exerted an influence over its appearance and, subsequently, on the death of the patient. Other factors identified as independent risk factors were chronic renal failure, diabetes mellitus, CPB time, respiratory failure, acute renal failure, and mediastinal bleeding of at least $1000 \mathrm{~mL}$. Moreover, these data support the need to develop effective strategies for the prevention of VAP. Implementation of such interventions should be costeffective because it should lower the incidence and lessen the sequelae of VAP.

\section{References}

[1] Kollef MH. Ventilator-associated pneumonia: a multivariate analysis. JAMA 1993;270:1965-70.

[2] Rebollo MH, Bernal JM, Llorca J, Rabasa JM, Revuelta JM. Nosocomial infections in patients having cardiovascular operations: a multivariate analysis of risk factors. J Thorac Cardiovasc Surg 1996;112:908-13. 
[3] Bouza E, Pérez A, Muñoz P, Jesús Pérez M, Rincón C, Sánchez C, et al, Cardiovascular Infection Study Group. Ventilator-associated pneumonia after heart surgery: a prospective analysis and the value of surveillance. Crit Care Med 2003;31:1964-70.

[4] Rello J, Ollendorf DA, Oster G, Vera-Llonch M, Bellm L, Redman R, et al. Epidemiology and outcomes of ventilator-associated pneumonia in a large US database. Chest 2002;122:2115-21.

[5] Bercault N, Boulain T. Mortality rate attributable to ventilatorassociated nosocomial pneumonia in an adult intensive care unit: a prospective case-control study. Crit Care Med 2001;29:2303-9.

[6] Warren DK, Shukla SJ, Olsen MA, Kollef MH, Hollenbeak CS, Cox MJ, et al. Outcome and attributable cost of ventilator associated pneumonia among intensive care unit patients in a suburban medical center. Crit Care Med 2003;31:1312-7.

[7] Fagon JY, Chastre J, Hance AJ, Montravers P, Novara A, Gibert C. Nosocomial pneumonia in ventilated patients: a cohort study evaluating attributable mortality and hospital stay. Am J Med 1993;94:281-8.

[8] Gross PA, Van Antwerpen C. Nosocomial infections and hospital deaths: a case control study. Am J Med 1983;75:658-61.

[9] Craig CP, Connelly S. Effect of intensive care unit nosocomial pneumonia on duration of stay and mortality. Am J Infect Control 1993;12:233-8.

[10] Craven DE, Kunches LM, Lichtenburg DA, Kollisch NR, Barry MA, McCabe WR. Nosocomial infection and fatality in medical and surgical intensive care unit patients. Arch Intern Med 1988;148:1161-8.

[11] Craven DE, Kunches LM, Kilinsky V, Lichtenberg DA, Make BJ, McCabe WR. Risk factors for pneumonia and fatality in patients receiving continuous mechanical ventilation. Am Rev Respir Dis 1986;133:792-6.

[12] Vincent JL, Bihari PM, Suter HA, Bruining J, White MH, NicolasChanion $\mathrm{M}$, et al. The prevalence of nosocomial infection in intensive care units in Europe: results of the European prevalence of infection in intensive care (EPIC) study. JAMA 1995;274:639-44.

[13] Fagon JY, Chastre J, Vuagnat A, Trouillet JL, Novara A, Gibert C. Nosocomial pneumonia and mortality among patients in intensive care units. JAMA 1996;275:866-9.

[14] Papazian L, Bregeon X, Thirion R. Effect of ventilator-associated pneumonia on mortality and morbidity. Am J Respir Crit Care Med 1996;154:91-7.

[15] Bueno-Cavanillas R, Delgado-Rodriguez A, Lopez-Luque S, SchaffinoCana S, Galvez-Vargas R. Influence of nosocomial infection on mortality rate in an intensive care unit. Crit Care Med 1994;22:55-60.

[16] Vallés J, Pobo A, García-Esquirol O, Mariscal D, Real J, Fernández R. Excess ICU mortality attributable to ventilator-associated pneumonia: the role of early vs late onset. Intensive Care Med 2007;33:1363-8.

[17] Melsen WG, Rovers MM, Bonten MJ. Ventilator-associated pneumonia and mortality: a systematic review of observational studies. Crit Care Med 2009;37:2709-18.

[18] Leal-Noval SR, Marquez-Vácaro JA, García-Curiel A, CamachoLaraña P, Rincón-Ferrari MD, Ordoñez-Fernández A, et al. Nosocomial pneumonia in patients undergoing heart surgery. Crit Care Med 2000;28:935-40.

[19] Tamayo E, Gualis J, Florez S, Castrodeza J, Eiros JM, Alvarez J. Comparative study of single-dose and 24-hour multiple-dose antibiotic prophylaxis for cardiac surgery. J Thorac Cardiovasc Surg 2008;136: 1522-7.

[20] Tobin MJ. Advances in mechanical ventilation. N Engl J Med 2001;344:1986-96.

[21] Kollef $\mathrm{MH}$. Inadequate antimicrobial treatment: an important determinant of outcome for hospitalized patients. Clin Infect Dis 2000;31: S131-8.

[22] Garner JS, Jarvis WR, Emori TG, Horan TC, Hughes JM. CDC definitions for nosocomial infections. Am J Infect Control 1988;16:128-40.

[23] Pugin J, Auckenthaler R, Mili N, Janssens JP, Lew PD, Suter PM. Diagnosis of ventilator-associated pneumonia by bacteriologic analysis of bronchoscopic and nonbronchoscopic "blind" bronchoalveolar lavage fluid. Am Rev Respir Dis 1991;143:1121-9.
[24] El-Hamamsy I, Cartier R, Demers P, Bouchard D, Pellerin M. Longterm results after systematic off-pump coronary artery bypass graft surgery in 1000 consecutive patients. Circulation 2006;114:486-91.

[25] van Swieten JC, Koudstaal PJ, Visser MC, Schouten HJ, van Gijn J. Interobserver agreement for the assessment of handicap in stroke patients. Stroke 1988;19:604-7.

[26] Filsoufi F, Rahmanian PB, Castillo JG, Mechanick JI, Sharma SK, Adams DH. Diabetes is not a risk factor for hospital mortality following contemporary coronary artery bypass grafting. Interact Cardiovasc Thorac Surg 2007;6:753-8.

[27] Puskas JD, Williams WH, Mahoney EM, Huber PR, Block PC, Duke PG, et al. Off-pump vs conventional coronary artery bypass grafting: early and 1-year graft patency, cost, and quality-of-life outcomes: a randomized trial. JAMA 2004;291:1841-9.

[28] Allison PD. Logistic regression using the SAS system: theory and application. Cary, NC: SAS Institute, Inc; 1999.

[29] Belsley DA, Kuh E, Welsch RE. Regression diagnostics: identifying influential data and sources of collinearity. New York, NY: John Wiley and Sons, Inc; 1980.

[30] Kleinbaum DG, Kleinbaum DG, Muller KE. Applied regression analysis and other multivariable methods. Pacific Grove. CA: Duxbury Press; 1998

[31] Cox DR. Regression models and life tables. J R Stat Soc 1972;34: 187-220.

[32] Tuman MD, Mc Carthy RJ, March RJ, Najafe H, Ivankovich AD. Morbidity and duration of ICU stay after cardiac surgery. A model for preoperative risk assessment. Chest 1992;102:36-44.

[33] Nashef SA, Roques F, Michel P, Gauducheau E, Lemeshow S, Salamon R. European system for cardiac operative risk evaluation (EuroSCORE). Eur J Cardiothorac Surg 1999;16:9-13.

[34] Parsonnet V, Dean D, Bernstein AD. A method of uniform stratification of risk for evaluating the results surgery in acquired adult heart disease. Circulation 1989;79:I3-12.

[35] Nashef SA, Roques F, Hammill BG, Peterson ED, Michel P, Grover FL, et al, EurpSCORE Project Group. Validation of European System for Cardiac Operative Risk Evaluation (EuroSCORE) in North American cardiac surgery. Eur J Cardiothorac Surg 2002;22:101-5.

[36] Toumpoulis IK, Anagnostopoulos CE, DeRose JJ, Swistel DG. European system for cardiac operative risk evaluation predicts longterm survival in patients with coronary artery bypass grafting. Eur $\mathrm{J}$ Cardiothorac Surg 2004;25:51-8.

[37] Morris AC, Kefala K, Simpson AJ, Wilkinson TS, Everingham K, Kerslake D, et al. Evaluation of the effect of diagnostic methodology on the reported incidence of ventilator-associated pneumonia. Thorax 2009;64:516-22.

[38] Kollef MH, Sharpless L, Vlasnik J, Pasque C, Murphy D, Fraser VJ. The impact of nosocomial infections on patient outcomes following cardiac surgery. Chest 1997;112:666-75.

[39] Hortal J, Giannella M, Pérez MJ, Barrio JM, Desco M, Bouza E, et al. Incidence and risk factors for ventilator-associated pneumonia after major heart surgery. Intensive Care Med 2009;35:1518-25.

[40] Hortal J, Muñoz P, Cuerpo G, Litvan H, Rosseel PM, Bouza E. Ventilator-associated pneumonia in patients undergoing major heart surgery: an incidence study in Europe. European Study Group on Nosocomial Infections; European Workgroup of Cardiothoracic Intensivists. Crit Care 2009;13(3):R80.

[41] Kollef MH, Ward S. The influence of mini-BAL cultures on patient outcomes: implications for the antibiotic management of ventilatorassociated pneumonia. Chest 1998;113:412-20.

[42] Moine P, Timsit JF, Lassencede A, Troche G, Fosse JP, Alberti C, et al, The OUTCOMERA study group. Mortality associated with late onset pneumonia in the intensive care unit:results of multi-center cohort study. Intensive Care Med 2002;28:154-63.

[43] Leroy O, Meybeck A, d'Escrivan T, Devos P, Kipnis E, Georges H. Impact of adequacy of initial antimicrobial therapy on the prognosis of patients with ventilator-associated pneumonia. Intensive Care Med 2003;29:2170-3. 